\title{
Reflection of Humanistic Value in English Textbook: English Skills Perspective
}

\author{
Sri Arfani 1 , Juhana ${ }^{2}$, Nur Qalbi 3 \\ DOI: $10.35445 /$ alishlah.v13i3.598
}

\begin{abstract}
Article Info
Abstract

Keywords:

English Skills;

Humanistic;

Textbook;

Value

The study purpose was to find out humanistic values in English textbooks through English skills perspective. A good textbook has to have an impact on students' attitudes. The method used content analysis. The data is taken from discourse text, namely monologue, dialogue, and exercise. Two books were used for grades VII, VIII, and IX in Junior High School South Jakarta. The findings showed that each language skill in the English textbook has humanistic values with various types that refer to the value of character education. Listening skills have three values, namely 1) Freedom values are religion, independence, hard work. 2) Optimistic values are creativity, discipline, and curiosity. 3) Social values are caring for the environment and cooperation. Speaking skills has five values, namely 1) Freedom values are religion, independence, hard work. 2) Equation values are democratic and empathy. 3) Brotherhood values are friendly, responsible, and respectful respect. 4) Optimistic values are discipline and curiosity. 5) Social value is cooperation. Reading skills has three values, namely 1) the value of freedom is religion and independence. 2) The equality value are democratic and empathy. 3) Brotherhood values are friendly and responsible. 4) Optimistic values are discipline, respectively, creativity, and curiosity. 5) Social value is cooperation. Writing skills have three values, namely 1) the value of freedom is religion and independence. 2) Optimistic values are creative, and curiosity. 3) The social values are environmental, peace, love, patriotism or nationalism, and cooperation. English textbooks have human values for each English skill exposed to various values relevant to character values. Each humanistic value implies changes in student attitudes, both about the learning process and social life.
\end{abstract}

Kata kunci:

Keterampilan Bahasa

Inggris;

Humanistik;

Buku ajar;

Nilai

\section{Abstrak}

Tujuan penelitian ini adalah untuk mendapatkan nilai-nilai humanistik dalam buku teks bahasa Inggris melalui perspektif keterampilan bahasa Inggris. Buku ajar yang baik harus memberikan dampak pada sikap siswa. Metode yang digunakan adalah analisis isi. Data diambil dari teks wacana yaitu monolog, dialog, dan latihan. Dua buku digunakan untuk siswa kelas VII, VIII, dan IX di SMP Negeri Jakarta Selatan. Hasil penelitian menunjukkan bahwa setiap keterampilan berbahasa dalam buku teks bahasa Inggris memiliki nilainilai humanistik dengan berbagai jenis yang mengacu pada nilai pendidikan karakter. Dalam keterampilan menyimak memiliki 3 nilai, yaitu 1) Nilai kebebasan yaitu religius, mandiri, kerja keras. 2) Nilai Optimis adalah kreatif, disiplin, dan rasa ingin tahu. 3) Nilai-nilai sosial peduli lingkungan dan gotong royong. Dalam keterampilan berbicara memiliki 5 nilai, yaitu 1) Nilai kebebasan yaitu religius, mandiri, kerja keras. 2) Persamaan nilai bersifat demokratis dan

\footnotetext{
${ }^{1}$ Universitas Bina Sarana Informatika, Jakarta, Indonesia

Email: sri.saf@bsi.ac.id

${ }^{2}$ Universitas Terbuka, Banten, Indonesia

Email: juhana@ecampus.ut.ac.id

3 Universitas Muhammadiyah Makasar, Makasar, Indonesia

Email: qalbi@unismuh.ac.id
} 
empati. 3) Nilai persaudaraan adalah ramah, bertanggung jawab, dan saling menghormati. 4) Nilai Optimis adalah disiplin dan rasa ingin tahu. 5) Nilai sosial adalah kerjasama. Dalam keterampilan membaca memiliki 3 nilai, yaitu 1) nilai kebebasan beragama dan kemandirian. 2) Nilai kesetaraan bersifat demokratis dan empati. 3) Nilai persaudaraan yang ramah, dan bertanggung jawab. 4) Nilai Optimis yaitu disiplin, kreatif, dan rasa ingin tahu. 5) Nilai sosial adalah kerjasama. Dalam keterampilan menulis memiliki 3 nilai, yaitu 1) nilai kebebasan beragama dan kemandirian. 2) Nilai optimis adalah kreatif, dan rasa ingin tahu. 3) Nilai-nilai sosial adalah lingkungan, cinta damai, patriotisme atau nasionalisme, dan kerjasama. Buku teks bahasa Inggris memiliki nilai-nilai kemanusiaan untuk setiap keterampilan bahasa Inggris yang terpapar dengan berbagai macam nilai yang relevan dengan nilai karakter. Setiap nilai humanistik berimplikasi pada perubahan sikap siswa, baik dalam kaitannya dengan proses pembelajaran maupun dalam kehidupan bermasyarakat.

\section{INTRODUCTION}

Education must create human beings ready and existent to live during changing times. Therefore, the teacher must be directly responsible for the value of education in the school. It can show in the learning process (Şahinkayasi \& Kelleci, 2013). The students are not being affected, but we cannot resist change because change is necessary. So that humans do not immerse themselves in the currents which receive them, but they can control the flow of change, and at the same time, choose where the life of society will be held and created by educational goals. Changes that arise from these conditions are attitudes, knowledge and behaviour related to their abilities. This is built on their efforts, as educators become facilitators in bridging these changes. Education is a process to help humans develop themselves to deal with changing situations. Education is needed by humans whenever they are and wherever they are. Education must produce quality human beings because the environment influenced human life (Feszterova \& Jomova, 2015) and have a noble character. Besides, they also faced the global situation (O'Flaherty \& Liddy, 2018). The provision of education cannot be separated from humans born with unique and different personalities from one another. It can be concluded that education must bridge the inherent traits that reflect human needs. Education and learning should be improved, balancing aspects of individuality and aspects of sociality or community life as human society. It should also be returned to the human aspects that need to be nurtured and developed in students. The phenomenon in schools or the world of education always presents good values, but many things are contrary to these good values. Students are still considered savings filled by the teacher so that what happens is not communication but a statement from the teacher that the student must accept obediently.

It knows that education is not a means to develop students' potential. Still, instead, it makes them human beings who are ready for certain interests. So that the learning process is implemented jointly and humanist. The knowledge about existing values with the ability to make something useful in life and the future thinking soul can be internalized in a person. In other words, an educational process that humanity humans are created. The concept of humanities teaches humans to have a deep sense of humanity. Eliminating selfish, authoritarian and individualistic traits does not arbitrarily force the other person to understand our conversation. The teacher can prepare students for globalization and the development of science and technology is by understanding humanistic values in the educational process because humanistic values education views humans as humans, namely living creatures created by God. with a certain nature to be developed optimally and optimally. The educational process is constantly changing, with changes in educational strategies from time to time. Humanism provides significant direction in this achievement (Rachmahana, 2008).

One way that can be done to provide an understanding of humanistic values to students is to integrate textbooks containing humanistic values. The psychology of humanism pays attention to teachers as facilitators. Humanism is suitable to be applied to learning materials that are personality 
formation, conscience, change attitudes, and analysis of social phenomena. Therefore, textbooks must contain these values so that students can become good personalities (Yanasari, 2016).

Many studies have examined textbooks related to educational values. English textbooks for secondary schools must be able to present new values. This can be designed to refer to multiple intelligences (Yeganeh \& Dezfouli, 2015). The Academic Turkish Word List covers 32\% of the academic corpus in Turkey. It supports international students in studying Turkish. They can improve reading comprehension skills. Therefore, the textbook is very well designed to list Turkish words of an academic nature (Dolmacı \& Ertal, 2016; Kirkgöz, 2009). It is different from Safi'i, Witdianti, Tarmin, \& Yanti (2020) study that they designed Indonesian language textbooks to improve their high critical thinking skills (Safi'i et al., 2020). Besides, textbooks must also have topics and texts in the context of communication needs, diversity and cultural representation so that students can build tolerance values (Huang, 2019; Zarei \& Khalessi, 2011). So, the teacher must be able to make adjustments in using the material in the textbook (Hanifa, 2018). Textbooks must also be designed according to the curriculum (W. Cheng, Lam, \& Kong, 2019).

Textbooks are a part of teaching material. Textbooks are also part of the curriculum that can help the role of teachers and students in the teaching and learning process. Therefore, textbooks are a very important component in the teaching and learning process. Hutchinson and Torres stated that the textbook is a possible agent for change (Crawford, 2003). Teachers are very autonomous in their textbook use, and it is likely a minority of teachers follow the text in the page by page manner suggested in the literature (Murray \& Christison, 2011). Some factors that influenced in arranging the textbook are 1) content, 2) teacher (belief, training, pedagogic and knowledge content, experience, teaching style, perception and evaluation of textbooks, attitudes), 3) students (skill level, previous learning experience), 4) class (design), and 5) school (Harwood, 2014).

Tomlinson suggests that 1) personalization and localization of materials; 2) flexibility and creativity of use; 3) respect for the learners; 4) engaging content; 5) multicultural perspective and awareness; 6) opportunities for the learners with experiential; 7) attempts made to engage the learner in the language learning process as an experienced, intelligent and exciting individual; 8) attempts made to use multidimensional approaches to language learning (Tomlinson, 2013). In selecting a good textbook, one must understand every criterion of a good textbook. According to Cunningsworth (1995), (1) coursebooks should correspond; to learners' needs. They should match the aims and objectives of the language program; (2) coursebooks should reflect the uses (present or future) that learners will make of the language. Textbooks should be chosen that will help equip students to use language effectively for their purpose; (3) coursebooks should take account of students, need as learners and should facilitate their learning processes, without dogmatically imposing a right "method"; (4) the coursebook should have a clear role as a support for learning, like teachers, they should mediate between the target language and the learner.

Thus, it is concluded that a good textbook can direct students to study independently (Harwood, 2014) because the teacher's role in the room is also limited. Books must help or fill in these weaknesses to get used to developing independent learning patterns. A good book also provides direction that leads to the competence to understand the context or meaning of values or characters relevant to the life that students experience in their daily lives as humans who live in the environment and social life.

A value is defined as a principle that promotes well-being or prevents harm (Naagarazan, 2006). It means that everyone must have guiding values to understand and live the paradigm of life. Because value is a belief about the view of something to act based on his choice, everyone feels he has a sense of respect. In this case, a person can build a sense of human value, one of the foundations. In general, humanism is a way of life that focuses on humans to achieve the ideal life, namely human happiness. This is a way of life used to achieve a higher degree of humanity, a more advantageous life, peace and happiness. Humanitarianism includes solidarity among human beings, respecting human dignity, equality and mutual help, respecting differences in various dimensions between 
humans, creating peace. Character as a noble value is a choice of behaviour built based on values believed. It is often positioned as an instrumental value or a way of achieving something against something (Hafid et al., 2012).

Humanistic value is a quality that shows how to behave as a human being and behave with benevolence (Samanai \& Haryanto, 2011). According to Small, there are five main humanistic values, among others; 1) values focus on interpretation and evaluation with absolute essential elements. This shows the differences between humans. 2) Humanistic values are useful for the social needs of society through government attention, such as the value of education. 3) Values contribute to the happiness of others both individually and in groups. 4) Democratic values. So, it leads to freedom. 5) Humanistic values lead to interests, such as concern for others (Small, 2013). While, Naagarazan stated that there are five main humanistic values, namely; 1) right conduct, 2) peace, 3) truth, 4) love and 5) non-violence (Naagarazan, 2006).

Of the five values, it can be seen that the first value is related to social values, self-care values, and ethical values. The second value refers to the value of peace, leading to the value of freedom and democracy with equality and upholding equality. The third value refers to the level of truth of each person's behaviour and attitude. The fourth value refers to love, which is social. The fifth value is the brotherhood. Humanistic values are qualities that show how to behave and behave as humans that describe certain characteristics. In Small and Naagarazan's opinion, five values related to humanistic values will be examined in this study, including five basic humanistic values, namely freedom, equality, brotherhood, optimism, and social.

From previous research, it is concluded that textbooks are designed according to the needs of the curriculum, the cultural context of a country, and the diversity of social life. Besides, textbooks used in class must also build critical thinking concepts so that students' multiple intelligences can be implemented in their real life. However, this study has a different orientation because it evaluates English textbooks for intermediate levels for grades VII, VIII, and IX. This researcher examines the humanistic value that is represented in English language skills. It has been the novelty highlighted by the research. The English textbook is still related to the humanistic value in each language skill.

There are several reasons that this research is essential to do, namely (1) English textbooks for junior high schools have a special role because they are the beginning or basis of the English language learning curriculum. (2) Junior high school is adolescence, that is, children aged 13-15 years. During this period, the children deliberately train themselves. Besides, in the junior high school environment, we can do it as a lesson for noble values as a life guide that is used to achieve a higher degree of humanity, a more advantageous life, peace and happiness. Humanity in this study is humanistic values in terms of English language skills.

Therefore, the research aims to obtain in-depth information about the concept of human values in the English textbook used in Junior High Schools in South Jakarta. Thus, the results of this research analysis are expected to provide input for teachers or book writers in designing English textbooks that can suit the changing needs of times and the demands of the curriculum for graduates.

\section{METHODS}

This study used a qualitative approach to content analysis methods. Qualitative research is a study of the phenomena that occur or facts (Creswell \& Creswell, 2018). In this case, the researchers studied the humanistic values in English textbooks for Public Middle Schools in South Jakarta. Therefore, the setting of this research is the textbooks of English lessons in South Jakarta used by grades VII, VIII, and IX. There are two books which are "Scaffolding" by Joko Priyana, Riandi, and Anita P. Mumpuni, and "In Focus" by Artono Wardiman, Masduki B. DJahur, and M. Sukirman Djusma. They are published by the Book Center of the Ministry of Education. National.

The research data is discourse texts directly related to humanistic values in English textbooks. The research instrument is a work table to classify the values contained in textbooks. The texts used are in monologues, dialogues and exercise texts. The research data collection procedure 
was carried out by 1) reading deeply and understanding both explicitly and implicitly in all books; 2) giving marks to expressions that have or contain humanistic values; 3) Grouping based on humanistic aspects; 4) tabulating types of humanistic values.

The data analysis technique used Mayring's theory (Mayring, 2014), namely (1) problem formulation; (2) selecting or categorizing data sources; (3) describing data categories; (4) checking reliability; and (5) data analysis. Checking the validity of the research data was carried out by serious reading, checking, and intensifying data analysis. Besides, the results of data analysis were also confirmed in (confirmability) with competent experts according to the object of study in research and colleagues. Then, the researcher conducted an assessment on the aspect of credibility. Strategies to increase data credibility with research persistence is intended to find characteristics and elements in situations relevant to the research issue to find the depth of research.

\section{FINDINGS AND DISCUSSION}

The data classified using the worktable is analyzed according to the category per language skills. Humanistic values found in the presentation of various language skills include freedom, equality, brotherhood, optimism, and social values.

\section{Listening Skills}

The humanistic value found in listening skills was $26.7 \%$ or 43 consisting of monologue texts as much as $23 \%$ or 10 data, dialogue texts as much as $16 \%$ or 7 data, and exercise texts as much as $61 \%$ or 26 data. It can be concluded that the data which dominates listening skills is exercise data. There are 3 humanistic values found, namely; 1) freedom values as much as $44 \%$ or 19 data consisting of religious values, independence, and hard work, 2) optimistic values as much as $25.6 \%$ or 11 data consisting of creative values, discipline, curiosity, and 3) social values as much as $30.4 \%$ or 13 data consisting of environmental care and curiosity. The purpose of listening learning is to good listening skills to easily listen to all conversations in English. Here is the detailed data;

a. The value of freedom was found to be $44 \%$ or 19 data.

1) The value of religion. It has implications for learning to listen in class, namely how students have confidence in listening learning, making it more accessible because listening is challenging with no habituation, especially when English has a different speech.

2) The value of independence. It has implications for learning to listen in class to provide a sense of freedom and confidence in knowing so that students do not depend on the teacher when they do not understand the material. Students easily complete all study assignments without depending on others when they have an independent character.

3) The value of hard work has implications for listening learning; namely, students always make serious efforts to complete assignments and listen to the material without giving up. The value of hard work shapes the attitudes and souls of students who are aware of the learning process that must be passed during school and understand the benefits of engaging in social life.

b. Optimistic value is $25,6 \%$ or 11 data.

1) The creative value. It has implications for listening in class, namely, creating new and innovative ideas in solving listening questions. Students will have a strategy in listening to text or dialogue.

2) The discipline value. It has implications for listening learning, namely the accuracy of the text or dialogue that it hears. The attitude of this value is that students can control themselves in using learning strategies.

3) The value of curiosity. It has implications for listening, where students are willing to repeatedly listen to the texts or dialogues on an ongoing basis to have a strong soul against a willingness to learn. 
c. Social value as much as $30.4 \%$ or 13 data.

1) The first social value is caring for the environment. This has implications for the formation of student character so that they always maintain and respect themselves, others and the environment well. In listening learning, students will care about themselves to study seriously.

2) The second value is cooperation. This value has implications for developing a caring attitude towards others. Students can easily build collaboration with others or teamwork.

3) Based on the above explanation, it can be concluded that a. Listening skills, among others; 1) freedom values (religious values, independence, and hard work, 2) optimistic values (creative values, discipline and curiosity), and 3) social values (values caring for the environment and cooperation). The first dominating value in listening skills is the independence value of $59 \%$ or 11 data. This means that more than half of the phenomenon is the value of independence. This is evidenced by the presentation of listening material that directs students to do all tasks independently and confidently.

\section{Speaking Skills}

The humanistic value found in speaking skills was $34 \%$ or 55 data consisting of monologue texts as much as $18 \%$ or 10 data, dialogue texts as much as $45 \%$ or 25 data and exercise texts as much as $37 \%$ or 20 data. Speaking skills have five humanistic values, among others;

1) Freedom value as much as $32.7 \%$ or 18 data are consisting of religious value as much as $5.6 \%$ or 1 data, independence value as much as $77.8 \%$ or 14 data, hard work value as much as $11.1 \%$ or 2 data and honesty value as much as $5.6 \%$ or 1 data. The religious value has implications for learning to speak, where students are nurtured to have confidence and persistence in the actions taken. When speaking, they will be controlled, and applicable regulations. The value of independence has implications for the character education process, namely directing students' attitudes and behaviour to their abilities, without depending on others. In learning, students will practice speaking without depending on other people. But it focuses on the task that must be completed. The value of hard work has implications for learning to speak. That is, when students get assignments to practice speaking, they will make serious efforts to practice speaking by correct articulations. So, the teacher must continue to develop the character of hard work in every evaluation of student learning. The value of honesty has major implications for the learning process because honesty is the basic foundation of an attitude that reflects goodness. Like when learning to speak, students must honestly show the results of their work.

2) Equation value as much as $7.3 \%$ or 4 data consists of a democratic value of $75 \%$ or 3 data and a value of empathy as much as $25 \%$ or 1 data. The value of democracy has implications for the speaking learning process which is related to attitudes that show respect for differences in the abilities of others. Teachers must foster student behaviour to appreciate these differences. The value of empathy has implications for character education which leads students to develop a caring attitude towards others. Students can help each other to learn to speak.

3) The value of brotherhood as much as $7.3 \%$ or 4 data consists of a friendly value of $50 \%$ or 2 data, being responsible as much as $25 \%$ or 1 data and respectful respect as much as $25 \%$ or 1 data. The value of being friendly has implications for learning to speak, where students are taught to be easy to get along with so that the learning process can easily get to know each other and be familiar. The value of responsible has implications for the character development process of students who have the same rights. Because responsibility does not only talk about obligations, but also education about rights. Responsibility means the existence of students themselves as learners, where they have equal obligations and rights in terms of obtaining learning. The value of respect has implications for the formation of character, namely awareness of respecting oneself, others and the environment. Students who have respect easily respect others. When learning to practice conversational English, students can easily appreciate their less capable friends and keep pace with their peers to complete assignments. 
4) Optimistic value as much as $32.7 \%$ or 18 data consisting of the discipline as much as $5.6 \%$ or 1 data and curiosity value as much as $94.4 \%$ or 17 data. The values of discipline and curiosity. This value is related to developing student character education. Teachers can nurture students through assignments such as speaking practices. When students have the will and desire to learn, they can create a disciplined self-concept of life, namely being able to control themselves.

5) Social value as much as $9 \%$ or 5 data, for the value of cooperation as $100 \%$ or 5 data. The value of environmental care has implications for the development of character education for students who respect the environment, not only respect for themselves and others. For example, when learning to speak, students will respect their colleagues according to their abilities. The value of cooperation has implications for the development of the souls of students who want to help others. Such as helping friends who are less able to speak English through peer learning dialogue. This value is relevant to the helpful character value.

\section{Reading Skills}

The humanistic value found in reading skills was $24.2 \%$ or 39 data consisting of monologues as much as $53.8 \%$ or 21 data, dialogue texts as much as $2.6 \%$ or 1 data, and exercise texts as much as $43.6 \%$ or 17 data. In reading skills, five humanistic values were found, namely;

1) The value of freedom is as much as $30.8 \%$ or 12 data consisting of religious as much as $16.7 \%$ or 2 data and independence as much as $83.3 \%$ or 10 data. The value of freedom includes religious values and independence that have implications for developing a religious and independent character. This value is relevant to forming students' attitudes towards developing reading learning abilities. Students are taught to have attitudes and behaviours that are based on beliefs and independence without depending on others. These character values guide students in actions that are based on kindness and courage.

2) The equality value was $7.7 \%$ or 3 data, consisting of $66.7 \%$ democratic values or 2 data and the value of empathy as much as $33.3 \%$ or 1 data. The first value found in the value of equality is the value of democracy. It is relevant to character education. Students have the same obligations as other students, but this also applies to learning rights. Students are allowed to develop their abilities according to their respective capacities. The second value is empathy. This value is relevant to the value of the helpful character. Students who care for others will feel what other people feel. For example, in learning to read, students who have a good feeling level will understand the content of the reading according to the context and learning experience.

3) The value of brotherhood as much as $7.7 \%$ or 3 data consisted of a friend as much as $66.7 \%$ or 2 data and was responsible as much as $33.3 \%$. The value of friendship has implications for the character development of caring for others. Meanwhile, the value of responsible has implications for developing student attitudes that lead to respect for others, themselves and the environment

4) Optimistic value as much as $41 \%$ consisting of creative and disciplinary values of $6.25 \%$ or 1 data respectively, and curiosity as much as $87.5 \%$ or 14 data. The values of optimism are creativity, disciplined and curiosity. These three values have a close relationship. All three are relevant to the character values taught in the character education process. Students who have a creative and innovative level of imagination through new ideas result from the existence of the discipline they have. So, they also have a high level of desire to learn to obtain more in-depth information. This can also have implications for the reading learning process, namely how students can find new ideas in reading because of the discipline they have through their efforts and the desire to know something more deeply.

5) Social values are as much as $12.8 \%$ or 5 data for the value of cooperation and $100 \%$. The value of cooperation has implications for reading learning, namely the attitude of helping other students who cannot understand the reading. This is also relevant to the value of the helpful character. 


\section{Writing Skills}

The humanistic value found in writing skills is $15 \%$ or 24 data consisting of monologue texts as much as $29.2 \%$ or 7 data, dialogue texts as much as $4.2 \%$ or 1 data and exercise texts as much as $66.6 \%$ or 16 data. In writing skills, there are three humanistic values were found, namely;

1) The freedom values as much as $50 \%$ or 12 data consist of religious values as much as $16.7 \%$ or 2 data, and independence values as much as 10 data or $83.3 \%$. The religious value has implications for learning to write, namely that they can write which is controlled by belief. So, students will write good things because they are controlled with confidence and faith. The second value is independence which has implications for learning to write; namely, students can learn to write

2) The optimistic value is $16.7 \%$ or 4 data, consisting of creative value as much as $25 \%$ or 1 data and curiosity value as much as $75 \%$ or 3 data. The creative value has implications for learning to write, where students are taught to have an innovative attitude. They can develop their imagination to develop writing. This is relevant to creative and innovative character education. The second value is that curiosity has implications for writing, namely exploring students' will to develop their writing. This value is relevant to curious character education.

3) The social value is $33.3 \%$ or 8 data, which consists of environmental care value as much as $12.5 \%$ or 1 data, the value of peace-loving as much as $12.5 \%$ or 1 data, the value of patriotism or nationalism as much as $12.5 \%$ or 1 data and the value of cooperation as much as $62.5 \%$ or 5 data. The value of caring is for the environment. This has implications for the development of students' abilities in the environment, which is outlined in writing. This value is relevant to the development of moral values, namely caring. The second value is the love of peace. This has implications for writing, namely through an outpouring of desire to create peace. This is relevant to developing moral values to maintain the balance of life without conflict. The third value is love for the motherland or nationalism. This has implications for developing a nationalist character that directs students to love the country and nation. This value can also be expressed in learning to write through the development of homeland love stories. The fourth value is cooperation. This value has implications for the learning process of writing through group discussion activities to make it easier for students to write. So, this value is relevant to moral values, namely responsibility.

The results of data analysis found that all English textbooks have four language skills, namely listening, speaking, reading and writing skills. Every English textbook has a different pattern. The pattern in the English textbook "English in focus" is that each language skill has its block of learning activities. In the English textbook pattern, "Scaffolding" combines two language skills, namely blocks for listening skills and speaking skills. For reading skills is combined with writing skills.

The data findings indicate that textbooks have humanistic values for each English skill. Listening skills build the concept of freedom, optimism and social values. This relates to the human values that every student must possess through these values. Listening skills have three values, namely 1) Freedom values are religion, independence, hard work. 2) Optimistic values are creativity, discipline, and curiosity. 3) Social values are caring for the environment and cooperation.

Meanwhile, speaking skills show five human values: freedom, equality, brotherhood, optimism, and social. Each value refers to implementing human values, namely 1) Freedom values are religion, independence, hard work. 2) Equation values are democratic and empathy. 3) Brotherhood values are friendly, responsible, and respectful respect. 4) Optimistic values are discipline and curiosity. 5) Social value is cooperation.

Reading skills also have five humanistic values. Each value has values that refer to the implementation of human values, namely 1) the value of freedom are religious and independence. 2) The equality value are democratic and empathy. 3) Brotherhood values are friendly and responsible. 4) Optimistic values are discipline respectively, creativity, and curiosity. 5) Social value is cooperation. 
Writing skills have three humanistic values, namely 1) the value of freedom is religion and independence. 2) Optimistic values are creative, and curiosity. 3) The social values are environmental, peace-loving, patriotism or nationalism, and cooperation. The humanistic value contained in English textbooks is related to a positive attitude in demonstrating English learning (Rahimi \& Hassani, 2012). Besides, the textbook has a fundamental element that manages the language content, cultural content (Simsek, 2014), structure, and the concept of the curriculum (Lee, 2014) for the value are appropriate with the environment (Miguel, 2015). So, the textbook should present a selection of texts and activities that can make a difference in understanding grammar (Miller, 2011). This can impact the clarity of the meaning of the educational values to be taught. Thus, this study explains that textbooks have a very important role in facilitating the teaching process and assisting teachers in carrying out learning according to student needs (Farzaneh, Kohandani, \& Nejadansari, 2014; Badea \& Iridon, 2015). English textbooks have the potential to provide guidance in language learning and be a platform for introducing cultural diversity and tolerance and a medium for integrating knowledge across disciplines (Huang, 2019b).

Based on the finding data, it can be concluded that the humanistic values that dominate language skills are the values of independence and curiosity. It is known that everyone is born with the ability within himself to determine the direction of life, understand something or event and deal with problems faced in his life. Thus, these two finding values explain to readers that with the basic abilities possessed by humans, students are taught to become more independent people and have a desire to know something more broadly. The abilities that are owned when they are not further honed do not increase. So, the value of curiosity has enormous implications for improving students' basic abilities, especially in the learning process. Curiosity is everyone's natural desire to learn. This textbook bridges students in how they explore their abilities. For example, if students are allowed to learn about the environment, a curious urge to learn arises naturally, especially when equipped with assignments.

Students have something that is the best value to pursue. This value is raised in every language skill. Students will desire to satisfy their curiosity, fulfil their interest in something and find essential things through listening, speaking, writing and reading activities. Thus, the process of learning English becomes meaningful. At the same time, the value of independence has implications for the development of dependability. Students learn to become initiators, meaning that students have a high initiative spirit because of the involvement of students' independent feelings and thoughts. An independent person can direct his control to a clear learning process. Students know how to learn according to their abilities. Besides, students also have a high level of self-confidence. So, independent learning focuses on students' attention both on the process and learning outcomes. As in learning English, students are taught to be independent souls to use foreign languages.

Humanistic education is oriented towards human development, emphasizing human values and cultural values in education (Yasin et al., 2012). The main goal is normative and personality humanity. The personality that is developed that is intact, integrated with socio-cultural values, the personality itself can be observed from behaviour and experience. The main goal of humanist education is to form good family, community and state members who have a religious, democratic spirit, responsible, independent, creative, exemplary, honest, hard work, tolerance, trustworthy, forgiving, and reflective of change and renewal and able to use leisure time effectively. Like as religious values in textbooks refer to the identity of a person or nation that teaches the value of goodness (K. K. Y. Cheng \& Beigi, 2012; Behnam \& Mozaheb, 2013). In contrast, responsibility refers to the individual's sense of self-discipline in their behaviour (Tan, Mahadir Naidu, \& Jamil@Osman, 2018). 


\section{CONCLUSION}

Humanistic values were found from reviews of different language skills, among others; a) the humanistic value that dominates listening skills is the independence value of $59 \%$ or 11 data. More than half of the phenomena in the English textbooks presented are the value of independence. This is also evidenced by the presentation of listening material that directs students to do all tasks independently and confidently. b) The value that dominates speaking skills is the value of curiosity as much as $94.4 \%$ or 17 data. This means that almost all phenomena presented in English textbooks are optimistic values of curiosity. This value teaches students attitudes and behaviours that always seek to dig more profound knowledge. c) The dominant value in reading skills is the value of curiosity as much as $87.5 \%$ or 14 data. This means that a large part of the phenomenon is curiosity value. d) The value that dominates writing skills is $83.3 \%$ or 10 data independence. This means that most of the five aspects of humanistic values are the value of freedom of independence. This has implications for student character formation in an independent moral education process because independent students have attitudes and behaviours that are not dependent on others and can complete tasks seriously.

This study also provides recommendations on the educational practice process, especially learning English. Humanistic values in learning English allow students to develop according to their ability, talent and potential to learn languages because humanistic values make a teacher a facilitator for students. As educators are always expected to have the ability starting from the selection of textbooks used as teaching media and conveying content related to aspects of values, especially humanistic values and other values contained in books, to build the character and personality of students. The author of textbooks recommended that it can be used as input to add aspects of character, culture, morals and other values. They should pay close attention to all aspects of building the integrity of a textbook so that readers understand it. Besides, the pattern or structure of the presentation of learning material should be presented in a varied (not monotonous) manner, especially in the learning theme. The author can include audio for learning listening to maximize the learning objectives of listening. This study can be a material consideration for researchers who want to develop and deeply examine humanistic values applied directly to every lesson in the classroom. Researchers can research these humanistic values associated with cultural values prevailing in a community or other aspects of values. With this research, it is hoped to provide a positive stimulus to the next researcher. Researchers can carry out further research using other elements or aspects of humanistic values in textbooks to add information about writing quality textbooks.

\section{REFERENCES}

Badea, M., \& Iridon, C. (2015). Students' Evaluation of a Romanian Language Textbook. Procedia Social and Behavioral Sciences, 203, 303-309. https://doi.org/10.1016/j.sbspro.2015.08.299

Behnam, B., \& Mozaheb, M. A. (2013). Identity, Religion and New Definition of Inclusiveness in Iranian High School EFL Textbooks. Procedia - Social and Behavioral Sciences, 70, 10991108. https://doi.org/10.1016/J.SBSPRO.2013.01.164

Cheng, K. K. Y., \& Beigi, A. B. (2012). Education and religion in Iran: The inclusiveness of EFL (English as a Foreign Language) textbooks. International Journal of Educational Development, 32(2), 310-315. https://doi.org/10.1016/J.IJEDUDEV.2011.05.006

Cheng, W., Lam, P. W. Y., \& Kong, K. C. C. (2019). Learning English Through Workplace Communication: Linguistic devices for interpersonal meaning in textbooks in Hong Kong. English for Specific Purposes, 55, 28-39. https://doi.org/10.1016/J.ESP.2019.03.004

Crawford, J. (2003). The Role of Material in Language Classroom: Finding the Balance, Methodology in Language Teaching, ed,. Jack C. Richard and Willy A. Renandya. New York: Cambridge University Press.

Creswell, J. W., \& Creswell, J. D. (2018). Research Design: Qualitative, Quantitative, and Mixed Methods Approaches Fifth Edition. New York: SAGE Publications Inc. 
Cunningsworth, A. (1995). Choosing Your Coursebook. Heineman: Oxford.

Dolmacı, M., \& Ertal, A. (2016). Developing a Textbook-based Academic Turkish Wordlist 1. Procedia - Social and Behavioral Sciences, 232, 821-827. https://doi.org/10.1016/j.sbspro.2016.10.111

Farzaneh, N., Kohandani, M., \& Nejadansari, D. (2014). A Textbook Evaluation of Socio-cultural Contexts in Top Notch Series. Procedia - Social and Behavioral Sciences, 98, 472-481. https://doi.org/10.1016/j.sbspro.2014.03.442

Feszterova, M., \& Jomova, K. (2015). Character of Innovations in Environmental Education. Procedia - Social and Behavioral Sciences, 197, 1697-1702. https://doi.org/10.1016/J.SBSPRO.2015.07.222

Hafid, A. (2012). Konsep Dasar Ilmu Pendidikan. Bandung: Alfabeta.

Hanifa, R. (2018). Advances in Language and Literary Studies EFL Published Materials : An Evaluation of English Textbooks for Junior High School in Indonesia, (2009), 166-174.

Harwood, N. (2014). English Language Teaching Textbooks Content, Consumption, Production. New York: Palgrave Macmillan.

Huang, P. (2019a). Textbook interaction: A study of the language and cultural contextualisation of English learning textbooks. Learning, Culture and Social Interaction, 21, 87-99. https://doi.org/10.1016/J.LCSI.2019.02.006

Huang, P. (2019b). Textbook interaction: A study of the language and cultural contextualisation of English learning textbooks. Learning, Culture and Social Interaction, 21, 87-99. https://doi.org/10.1016/J.LCSI.2019.02.006

Kirkgöz, Y. (2009). Evaluating the English textbooks for young learners of English at Turkish primary education. Procedia - Social and Behavioral Sciences, 1(1), 79-83. https://doi.org/10.1016/j.sbspro.2009.01.016

Lee, J. F. K. (2014). A hidden curriculum in Japanese EFL textbooks: Gender representation. Linguistics and Education, 27(1), 39-53. https://doi.org/10.1016/j.linged.2014.07.002

Mayring, P. (2014). Qualitative Content Analysis: Theoritical Foundation Base Procedures and Sofware Solutiaon. Austria: Klagenfurt.

Miguel, N. M. (2015). Textbook Consumption in the Classroom: Analyzing a Classroom Corpus. Procedia - Social and Behavioral Sciences, 198, 309-319. https://doi.org/10.1016/j.sbspro.2015.07.449

Miller, D. (2011). ESL reading textbooks vs. university textbooks: Are we giving our students the input they may need? Journal of English for Academic Purposes, 10(1), 32-46. https://doi.org/10.1016/J.JEAP.2010.12.002

Murray, D. E., \& Christison, M. A. (2011). What English Language Teachers Need to Konow Volume II Facilitating Learning. New York: Routledge.

Naagarazan, R. . (2006). Texbook on Profesional Ethics and Human Values. New Delhi: New Age Internasional.

O'Flaherty, J., \& Liddy, M. (2018). The impact of development education and education for sustainable development interventions: a synthesis of the research. Environmental Education Research, 24(7), 1031-1049. https://doi.org/10.1080/13504622.2017.1392484

Rachmahana, R. S. (2008). Psikologi Humanistik dan Aplikasinya dalam Pendidikan. El-Tarbawi, 1(1), 99-114. https://doi.org/10.20885/tarbawi.vol1.iss1.art8

Rahimi, M., \& Hassani, M. (2012). Attitude towards efl textbooks as a predictor of attitude towards learning english as a foreign language. In Procedia - Social and Behavioral Sciences (Vol. 31, pp. 66-72). Elsevier. https://doi.org/10.1016/j.sbspro.2011.12.018

Safi'i, I., Witdianti, Y., Tarmin, W., \& Yanti, G. (2020). HOTS Evaluation Instruments In Indonesian Language Textbooks. RETORIKA: Jurnal Bahasa, Sastra, Dan Pengajarannya, 13(2). https://doi.org/10.26858/retorika.v13i2.13694

Şahinkayasi, Y., \& Kelleci, Ö. (2013). Elementary School Teachers' Views on Values Education. Procedia - Social and Behavioral Sciences, 93, 116-120. https://doi.org/10.1016/J.SBSPRO.2013.09.162

Samanai, M., \& Haryanto. (2011). Pendidikan Karakter:Konsep dan Model. Bandung: Remaja Rosda Karya.

Simsek, M. R. (2014). Adapting a Turkish Middle School Textbook to Develop Cultural Awareness. Procedia - Social and Behavioral Sciences, 152, 199-204. https://doi.org/10.1016/j.sbspro.2014.09.181 
Small, H. (2013). The Value of the Humanities. Great Britain: Oxford University Press.

Tan, B. P., Mahadir Naidu, N. B., \& Jamil@Osman, Z. (2018). Moral values and good citizens in a multi-ethnic society: A content analysis of moral education textbooks in Malaysia. The Journal of Social Studies Research, 42(2), 119-134. https://doi.org/10.1016/J.JSSR.2017.05.004

Tomlinson, B. (2013). Developing Materials For Language Teaching second edition. New York: Bloomsbury.

Widyahening, E. T., \& Wardhani, N. E. (2016). Literary Works and Character Education. International Journal of Language and Literature, 4(1).

Yanasari, P. (2016). The Humanistic Approach to Change and the Development of Behavior in the Realm of Education. Nuansa, IX(2).

Yasin, M. S. M., Hamid, B. A., Othman, Z., Bakar, K. A., Hashim, F., \& Mohti, A. (2012). A Visual Analysis of a Malaysian English School Textbook: Gender Matters. Procedia - Social and Behavioral Sciences, 69, 1871-1880. https://doi.org/10.1016/J.SBSPRO.2012.12.140

Yeganeh, M. T., \& Dezfouli, F. B. (2015). The Reflection of Multiple Intelligences (MI) in Iranian English Textbooks, Teachers' Perception. Procedia - Social and Behavioral Sciences, 192, 1114. https://doi.org/10.1016/j.sbspro.2015.06.002

Zarei, G. R., \& Khalessi, M. (2011). Cultural load in English language textbooks: An analysis of interchange series. In Procedia - Social and Behavioral Sciences (Vol. 15, pp. 294-301). Elsevier. https://doi.org/10.1016/j.sbspro.2011.03.089 